JURNAL NUANSA INFORMATIKA

Volume 14 Nomor 2, Juli 2020
p-ISSN : 1858-3911, e-ISSN : 2614-5405

https://journal.uniku.ac.id/index.php/ilkom

\title{
ANALISIS PERBANDINGAN METODE AHP DAN TOPSIS DALAM PEMILIHAN ASISTEN LABORATORIUM DI FKOM UNIKU
}

\author{
Siti Maesyaroh \\ Fakultas Ilmu Komputer Universitas Kuningan. Jln Tjut Nyak Dhien No. 36 A Cijoho Kuningan \\ Jawa Barat 45513 Telepon (0232) 287509, Indonesia \\ Email : siti.maesyaroh@uniku.ac.id
}

\begin{abstract}
Sistem pemilihan asisten laboratorium merupakan sebuah aplikasi yang digunakan untuk menentukan mahasiswa yang layak menjadi asisten laboratorium berdasarkan hasil testing yang telah dilakukan. Tes yang dilakukan meliputi tes pemberkasan (persyaratan dokumen dan nilai minimal matakuliah praktikum serta ipk), tes wawancara, micro teaching dan tes tertulis (kompetensi). Pada sistem ini dapat digunakan dengan beberapa metode sebagai bahan analisa perbandingan. Penelitian ini membandingkan dua metode sistem pendukung keputusan yaitu Analytical Hierarchy Process (AHP) dan Technique for Order Preference by Similarity to Ideal Solution (TOPSIS). Perbandingan kedua metode ini dilakukan berdasarkan empat kriteria, yaitu nilai wawancara, tes tertulis, nilai akademik, dan microteaching. Pada penelitian ini diperoleh hasil yang berbeda dari masing-masing metode sehingga dapat mengetahui metode mana yang dapat memberikan hasil yang optimal untuk sistem pendukung keputusan pemilihan asisten laboratorium di Fakultas Ilmu Komputer Universitas Kuningan.
\end{abstract}

Kata Kunci : Sistem Pendukung Keputusan (SPK), Analytical Hierarchy Process (AHP), Technique For Order Preference by Similarity to Ideal Solution (TOPSIS).

Laboratory assistant selection system is an application that is used to determine students who are eligible to become laboratory assistants based on the results of testing that has been done. The tests include a filing test (document requirements and a minimum grade of practicum and IPK courses), an interview test, micro teaching and a written test (competency). In this system can be used with several methods as comparative analysis material. This study compares two methods of decision support systems namely Analytical Hierarchy Process (AHP) and Technique for Order Preference by Similarity to Ideal Solution (TOPSIS). Comparison of the two methods is based on four criteria, namely the value of interviews, written tests, academic grades, and microteaching. In this study obtained different results from each method so that it can find out which method can provide optimal results for the decision support system for the selection of laboratory assistants in the Faculty of Computer Science, Kuningan University.

Keywords: Decision Support System (SPK), Analytical Hierarchy Process (AHP), Technique For Order Preference by Similarity to Ideal Solution (TOPSIS).

\section{PENDAHULUAN}

Dalam memberikan sebuah keputusan selalu diupayakan secara objektif, cepat, dan tepat. Saat ini untuk mendukung dalam menentukan keputusan telah banyak menggunakan sistem pendukung keputusan. Berbagai metode telah diterapkan dalam membangun sistem pendukung keputusan agar menghasilkan alternative yang tepat. Metode tersebut diantaranya yaitu Analytical Hierarchy Process (AHP) dan Technique For Order Preference by Similarity to Ideal Solution (TOPSIS).

AHP adalah metode dalam sistem pengambilan keputusan yang menggunakan beberapa variabel dengan proses analisis 
JURNAL NUANSA INFORMATIKA

Volume 14 Nomor 2, Juli 2020

bertingkat. Analisis dilakukan dengan memberi nilai prioritas dari setiap variabel, kemudian melakukan perbandingan berpasangan dari variabel-variabel dan alternatif-alternatif yang ada. Adapun penelitian yang berkaitan dengan metode AHP yaitu penelitian yang dilakukan oleh Adriyendi dan Yeni Melia (2013) dalam sistem pendukung keputusan untuk pemilihan dosen di STAIN Batsangkar. Kriteria yang digunakan dalam pemilihan ini adalah pendidikan, kemampuan, pengetahuan, pengalaman, dan kepribadian. Penelitian ini dilakukan dengan menggunakan Microsoft Excel dan Expert Choice, dimana metode AHP dapat menghasilkan keputusan yang optimal dalam pemilihan dosen.

TOPSIS adalah metode pengambilan keputusan multikriteria yang pertama kali diperkenalkan oleh Yoon dan Hwang (1981). TOPSIS menggunakan prinsip bahwa alternative yang terpilih harus mempunyai jarak terdekat dari solusi ideal positif dan jarak terpanjang (terjauh) dari sudut pandang geometris dengan menggunakan jarak Euclidean (jarak antara dua titik) untuk menentukan kedekatan relative dari suatu alternative dengan solusi optimal. Adapun penelitian yang menggunakan TOPSIS yaitu penelitian yang dilakukan oleh Irvan Muzakkir (2017) untuk sistem pendukung keputusan penentuan keluarga miskin yang mampu memberikan hasil yang maksimal dalam hal pengambilan keputusan dengan cara mengurutkan alternatif masyarakat miskin mulai dari termiskin.

Penelitian yang berkaitan dengan perbandingan metode AHP dan TOPSIS telah dilakukan oleh Adi Suwarni (2016) untuk menentukan mata kuliah peminatan bagi mahasiswa. Penelitian tersebut menggunakan kriteria yaitu APSI sebagai kriteria 1, Algoritma sebagai kriteria ke 2, Pemrograman sebagai kriteria 3, basis data sebagai kriteria ke 4, PTI sebagai kriteria ke 5, Jarkom sebagai kriteria ke 6, dan SO sebagai kriteria ke 7, berkaitan dengan matakuliah peminatan dari beberapa alternatif yang ada berupa NPM Mahasiswa sebanyak 5. Hasil dari penelitian tersebut menyatakan bahwa metode TOPSIS
p-ISSN : 1858-3911, e-ISSN : 2614-5405

https://journal.uniku.ac.id/index.php/ilkom

adalah metode yang paling lengkap dan paling tepat digunakan dalam menyelesaikan masalah pengambilan keputusan dari beberapa kriteria (atribut) dalam menentukan peminatan. Sedangkan dalam metode AHP diperlukan perbandingan berpasangan untuk menentukan pembobotan kriteria dan perhitungan yang berulang ulang untuk mendapatkan nilai peminatan, setiap mahasiswa akan melakukan pengulangan sebanyak 5 kali untuk menghasilkan nilai peminatannya.

Oleh karena itu, penulis akan melakukan penelitian untuk membandingkan metode AHP dan TOPSIS pada pemilihan asisten laboratorium di fkom uniku dengan menggunakan kriteria yang lebih sedikit dan alternatif yang lebih banyak dari penelitian yang sudah ada. Sehingga dapat mengetahui kelemahan dan kelebihan dari masing-masing metode tersebut.

\section{METODE PENELITIAN}

Penelitian yang dilakukan penulis bersifat deskriptif dengan menggunakan data-data hasil observasi langsung. Metode analisa data berdasarkan landasan teori tentang sistem pendukung keputusan. Berdasarkan hal tersebut, maka metode pendekatan penelitian ini dinamakan sebagai penelitian deskriptif kualitatif.

Diagram alir dari metode penelitian yang dilakukan dalam penelitian ini dapat dilihat pada Gambar 1.

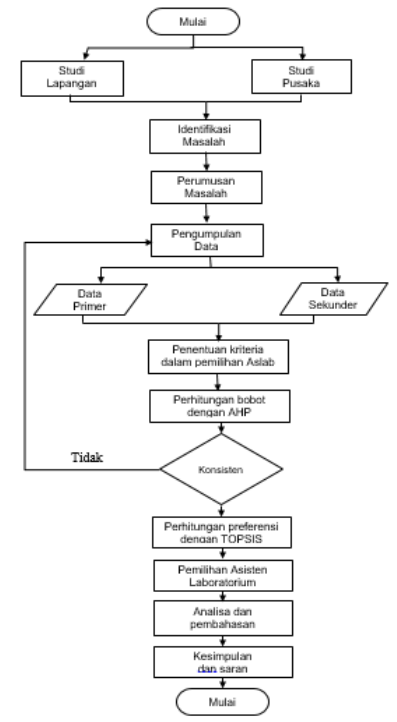

Gambar 1. Diagram Alir Metode Penelitian 
JURNAL NUANSA INFORMATIKA

Volume 14 Nomor 2, Juli 2020

\subsection{Prototype Model}

Prototype merupakan salah satu metode pengembangan perangkat lunak yang banyak digunakan. Dengan metode prototyping ini pengembang dan pelanggan dapat saling berinteraksi selama proses pembuatan sistem.

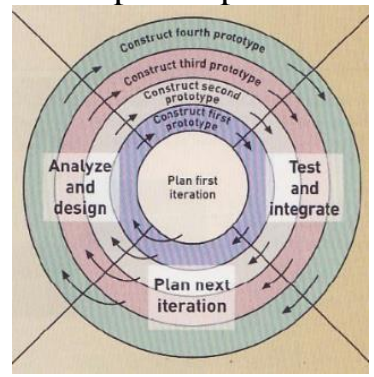

Gambar 2. Tahapan Prototype Model (Pressman, Roger S, 2007).

a. Pengumpulan Kebutuhan

Pelanggan dan pengembang bersamasama mendefinisikan format seluruh perangkat lunak, mengidentifikasikan seluruh kebutuhan dan garis besar system yang akan dibuat. Pada tahp ini ditentukan sampel data yang akan diolah beserta variabel yang akan diamati.

b. Merancang dan membangun prototyping

Pada tahap ini, dilakukan perancangan menggunakan UML dan pembuatan prototype sistem. Prototype dibuat sesuai dengan kebutuhan sistem yang telah didefinisikan sebelumnya. Untuk pengolahan data diterapkan metode Analytical Hierarchy Process (AHP) ke dalam sistem. Tahapan dalam metode Analytical Hierarchy Process (AHP) dapat dilihat pada Gambar 2.

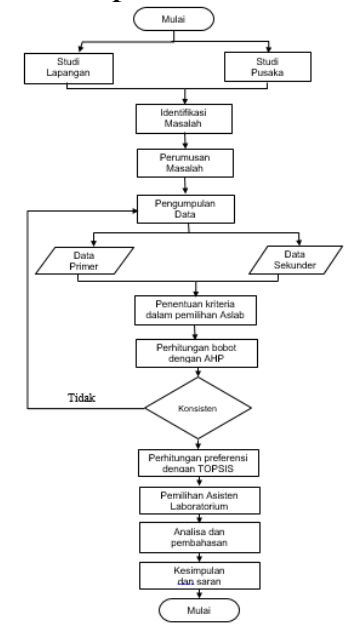

Gambar 3. Tahapan Metode AHP dan TOPSIS
p-ISSN : 1858-3911, e-ISSN : 2614-5405

https://journal.uniku.ac.id/index.php/ilkom

\section{c. Menguji Sistem}

Sistem yang telah menjadi perangkat lunak siap pakai, diuji terlebih dahulu menggunakan pengujian Black Box dan White Box. Dimana pada pengujian Black Box dilakukan pengujian kesesuaian Antara input dan output, sedangkan pengujian White Box dilakukan dengan pengujian fungsi program. Pengujian dilakukan oleh pengguna untuk mengevaluasi prototype yang dihasilkan jika terdapat kekurangan dari kebutuhan pengguna atau pun adanya pengembangan maka prototype akan diperbaiki kembali.

\subsection{Teknik Pengumpulan Data}

Metode pengumpulan data sangat dibutuhkan untuk keperluan penentuan bobot rangking baik kriteria maupun alternative. Tahap pengumpulan data dilakukan dengan wawancara, observasi dan studi literature/pustaka.

a. Metode Wawancara

Metode wawancara merupakan cara langsung untuk mendapatkan data secara rinci dan dapat dipakai sebagai landasan pertama untuk melakukan penelitian yang lebih dalam. Hasil dari data tersebut dapat digunakan sebagai gambaran dari masalah-masalah yang diteliti. Data tersebut diperoleh dari berbagai sumber yang diwawancarai. Adapun wawancara yang dilakukan dalam penelitian ini dengan melakukan sesi tanya jawab kepada Kepala Laboratorium Fakultas Ilmu Komputer Universitas Kuningan untuk menentukan format penilaian dalam memilih asisten laboratorium.

b. Metode Obsevasi

Observasi dilakukan untuk menyesuaikan hasil wawancara yang diperoleh dengan melakukan observasi langsung ke tempat kegiatan.

c. Metode Studi Literatur/Pustaka

Studi Pustaka merupakan cara pengumpulan data yang dilakukan penulis dengan mempelajari landasan teori dari berbagai sumber, seperti buku, artikel, dan jurnal-jurnal penelitian yang terkait dengan penelitian. Penulis mempelajari langsung teori- 
JURNAL NUANSA INFORMATIKA

Volume 14 Nomor 2, Juli 2020

teori analisa perbandingan dua metode sistem pendukung keputusan. Untuk daftar literature tersebut terlampir dalam daftar pustaka.

\subsection{Asisten Laboratorium (Aslab)}

Berdasarkan SOP UPT Laboratorium FKOM UNIKU (2013), Asisten laboratorium adalah mahasiswa yang diberi tugas oleh Pihak Laboratorium (atas izin Fakultas) untuk mendampingi dosen praktikum dan praktikan selama kegiatan praktikum berlangsung.

\subsection{Analytical Hierarchy Process (AHP)}

Analytical Hierarchy Process (AHP) adalah sebuah hierarki fungsional dengan input utamanya persepsi manusia. Metode ini dikembangkan oleh Prof. Thomas Lone Saaty dari Wharton Business Scholl di awal tahun 1970, yang digunakan untuk mencari ranking atau urutan prioritas dari berbagai alternative dalam pemecahan suatu permasahan (Johannes, 2009).

Dalam menyelesaikan permasalahan dengan AHP ada beberapa prinsip yang harus dipahami, yaitu (Saaty, 200) :

1. Decomposition (membuat hierarki )

Sistem yang kompleks bisa dipahami dengan memecahkannya menjadi elemenelemen yang lebih kecil dan sudah dipahami.

2. Comparative Judgment

Kriteria dan alternative dilakukan dengan perbandingan berpasangan sehingga dapat diketahui skala kepentingan dari masingmasing kriteria tehadap kriteria lainya.

3. Synthesis of priority (menentukan prioritas)

4. Logical Consistency (mengukur konsistensi dari elemen prioritas relative)

Secara umum pengambilan keputusan dengan metode AHP didasarkan pada langkah - langkah berikut :

a. Mendefinisikan masalah dan menentukan solusi yang diinginkan, kemudian menyusun hierarki dari permasalahan yang dihadapi.

b. Menentukan prioritas elemen
p-ISSN : 1858-3911, e-ISSN : 2614-5405

https://journal.uniku.ac.id/index.php/ilkom

1. menentukan prioritas elemen dengan membuat perbandingan pasangan, yaitu membandingkan elemen secara berpasangan sesuai kriteria yang diberikan.

2. Matriks perbandingan berpasangan diisi menggunakan bilangan untuk merepresentasikan kepentingan relatif dari suatu elemen terhadap elemen yang lainnya.

c. Sintesis

Pertimbangan-pertimbangan terhadap perbandingan berpasangan disintesis untuk memperoleh keseluruhan prioritas. Hal-hal yang dilakukan dalam langkah ini adalah :

1. Menjumlahkan nilai-nilai dari setiap kolom pada matriks

2. Membagi setiap nilai dari kolom dengan total kolom yang bersangkutan untuk memperoleh normalisasi matriks.

3. Menjumlahkan nilai-nilai dari setiap baris dan membaginya dengan jumlah elemen untuk mendapatkan nilai ratarata.

d. Mengukur konsistensi

Dalam pembuatan keputusan, penting untuk mengetahui seberapa baik konsistensi yang ada. Hal-hal yang dilakukan dalam langkah ini adalah :

1. Kalikan setiap nilai pada kolom pertama dengan prioritas relatif elemen pertama, nilai pada kolom kedua dengan prioritas relatif elemen kedua dan seterusnya.

2. Jumlahkan setiap baris

3. Hasil dari penjumlahan baris dibagi dengan elemen prioritas relatif yang bersangkutan

4. Jumlahkan hasil bagi di atas dengan banyaknya elemen yang ada, hasilnya disebut $\lambda$ maks

e. Melakukan perhitungan Consistency Index $(\mathrm{CI})$ dengan rumus :

$\mathrm{CI}=(\lambda \max -\mathrm{n}) / \mathrm{n}$

Dimana $\mathrm{n}=$ banyaknya elemen

f. Melakukan perhitungan rasio konsistensi /

Consistency Ratio (CR) dengan rumus :

$\mathrm{CR}=\mathrm{CI} / \mathrm{IR}$ 
JURNAL NUANSA INFORMATIKA

Volume 14 Nomor 2, Juli 2020

Dimana

$\mathrm{CR}=$ Consistency Ratio

$\mathrm{CI}=$ Consistency Index

IR = Indeks Random Consistency

g. Memeriksa konsistensi hierarki. Jika nilainya lebih dari $10 \%$ maka penilaian data judgment harus diperbaiki. Namum jika rasio konsistensi (CI/CR) kurang atau sama dengan 0,1 maka hasil perhitungan bisa dinyatakan benar, dimana nilai RI atau random index, dapat dilihat pada tabel 1.

Tabel 1. Nilai Indeks Random

\begin{tabular}{|l|l|l|l|l|l|l|l|l|l|l|}
\hline $\mathrm{N}$ & 1 & 2 & 3 & 4 & 5 & 6 & 7 & 8 & 9 & 10 \\
\hline $\mathrm{RI}$ & 0 & 0 & 0.58 & 0.90 & 1.12 & 1.24 & 1.32 & 1.41 & 1.45 & 1.49 \\
\hline
\end{tabular}

2.5 Technique For Order Preference by Similarity to Ideal Solution (TOPSIS)

TOPSIS adalah metode yang dikenalkan pertamakali oleh Yoon dan Hwang, dimana alternatif yang dipilih memiliki jarak terdekat dengan solusi ideal positif dan memiliki jarak terjauh dari solusi ideal negatif. Berikut adalah langkah-langkah dalam TOPSIS :

1. Normalisasi matriks keputusan

Setiap elemen pada matriks D dinormalisasikan untuk mendapatkan matriks normalisasi R. Setiap normalisasi dari nilai rij dapat dilakukan perhitungan seperti pada rumus berikut :

$r_{i j}=\frac{x_{i j}}{\sqrt{\sum_{j=1}^{m} x_{i j}^{2}}}$,

untuk $i=1,2,3, \ldots, m ; j=1,2,3, \ldots, n$

2. Pembobotan pada matriks yang telah dinormalisasikan Diberikan bobot $\mathrm{W}=$ (w1,w2, .,wn), sehingga weighted normalized matriks $\mathrm{V}$ dapat dihasilkan seperti pada rumus :

$$
y=\left[\begin{array}{cccc}
y_{11} & y_{12} & \ldots & y_{i j} \\
y_{21} & y_{22} & \ldots & y_{2 j} \\
\vdots & \vdots & \ddots & \vdots \\
y_{i 1} & y_{i 2} & \ldots & y_{i j}
\end{array}\right]
$$

dengan $\mathrm{i}=1,2,3, \ldots, \mathrm{m}$ dan $\mathrm{j}=1,2,3 \ldots, \mathrm{n}$

3. Menentukan solusi ideal positif dan solusi ideal negatif

Solusi ideal positif dinotasikan dengan A+ dan solusi ideal negatif dinotasikan
p-ISSN : 1858-3911, e-ISSN : 2614-5405

https://journal.uniku.ac.id/index.php/ilkom

dengan A-, seperti pada rumus berikut

$A^{+}=\left(y_{1}{ }^{+}, y_{2}{ }^{+}, \cdots, y_{j}{ }^{+}\right)$

$A^{-}=\left(y_{1}{ }^{-}, y_{2}{ }^{-}, \cdots, y_{j}{ }^{-}\right)$

Dimana :

vij = elemen matriks $\mathrm{V}$ baris ke-i dan kolom ke- $\mathrm{j}$

$\mathrm{J}=\{\mathrm{j}=1,2,3, \ldots, \mathrm{n}$ dan $\mathrm{j}$ berhubung dengan benefit criteria

$\mathrm{J}^{\prime}=\{\mathrm{j}=1,2,3, \ldots, \mathrm{n}$ dan $\mathrm{j}$ berhubung dengan cost criteria\}

4. Menghitung Separation Measure

Separation measure ini merupakan pengukuran jarak dari suatu alternatif ke solusi ideal positif dan solusi ideal negatif. Perhitungan matematisnya adalah seperti pada rumus berikut :

Separation measure untuk solusi ideal positif

$$
d_{i}^{+}=\sqrt{\sum_{j=1}^{m}\left(y_{i j}-y_{j}^{+}\right)^{2}}
$$

dengan $\mathrm{i}=1,2,3, \ldots, \mathrm{n}$

Separation measure untuk solusi ideal negative

$$
d_{i}{ }^{-}=\sqrt{\sum_{j=1}^{m}\left(y_{i j}-y_{j}^{-}\right)^{2}}
$$

5. Menghitung kedekatan relatif dengan ideal positif

Kedekatan relatif dari alternatif $\mathrm{A}+$ dengan solusi ideal Adirepresentasikan seperti pada rumus berikut :

$$
c_{i}=\frac{d_{i}^{-}}{d_{i}^{-}+d_{i}^{+}}
$$

dengan $0<\mathrm{C},<1$ dan $\mathrm{i}=1,2,3, \ldots, \mathrm{m}$

6. Mengurutkan pilihan

Alternatif dapat dirangking berdasarkan urutan Ci. Maka dari itu, alternatif terbaik adalah salah satu yang berjarak terpendek terhadap solusi ideal dan berjarak terjauh dengan solusi ideal negative.

\section{HASIL DAN PEMBAHASAN}

Hasil penelitian ini membahas mengenai rekapitulasi hasil tes asisten laboratorium yang dihasilkan dari nilai wawancara, nilai tertulis, nilai akademik, dan nalai microteaching yang diperoleh masing-masing mahasiswa. 
JURNAL NUANSA INFORMATIKA

Volume 14 Nomor 2, Juli 2020

Selanjutnya data tersebut dihitung dengan menggunakan metode AHP dan TOPSIS. Hasil perhitungannya akan ditunjukkan beserta nilai indeks konsistensi untuk mengetahui rangking asisten laboratorium yang dapat dijadikan sebagai bahan pertimbangan untuk menjadi asisten laboratorium.

Data utama yang disajikan untuk melakukan perhitungan pada metode AHP dan TOPSIS adalah data calon asisten laboratorium periode 2018/2019 yang bersumber dari data Labkom Fakultas Ilmu Komputer seperti pada tabel 2.

Tabel 2. Data hasil tes calon asisten laboratorium

\begin{tabular}{|c|c|c|c|c|}
\hline \multirow{2}{*}{ Alternative } & \multicolumn{4}{|c|}{ Kriteria } \\
\hline & $\begin{array}{c}\text { nilai } \\
\text { wawancara }\end{array}$ & $\begin{array}{c}\text { tes } \\
\text { tertulis }\end{array}$ & $\begin{array}{c}\text { nilai } \\
\text { akademik }\end{array}$ & microteaching \\
\hline $\begin{array}{l}\text { Wulan } \\
\text { Noviana N }\end{array}$ & 3.15 & 30 & 3.5 & 70.1 \\
\hline Elis & 2 & 36 & 3.63 & 64.15 \\
\hline Elsa Maitsa & 3.5 & 38 & 3.5 & 74.725 \\
\hline $\begin{array}{l}\text { Mirna } \\
\text { Sulistiani }\end{array}$ & 2.3 & 31 & 3.67 & 74.85 \\
\hline $\begin{array}{l}\text { Idam Idzin } \\
\text { Dimiati }\end{array}$ & 3.55 & 36 & 3.58 & 73.875 \\
\hline $\begin{array}{l}\text { Yani } \\
\text { Suryani }\end{array}$ & 2.6 & 30 & 3.6 & 67.8 \\
\hline $\begin{array}{ll}\text { Intan } & \text { Nur } \\
\text { Fitri } & \\
\end{array}$ & 3.1 & 35 & 3.5 & 71.5 \\
\hline $\begin{array}{l}\text { Assyfa } \\
\text { Savitri } \\
\text { Damayanti } \\
\end{array}$ & 3.2 & 32 & 3.5 & 70.5 \\
\hline Ero Rohim & 3.6 & 35 & 3.6 & 74.6 \\
\hline $\begin{array}{l}\text { Amelya } \\
\text { Puspita } \\
\text { Anggraeni } \\
\end{array}$ & 2.55 & 31 & 3.55 & 73.775 \\
\hline $\begin{array}{l}\text { Cici } \\
\text { Cahyani }\end{array}$ & 3.55 & 32 & 3.7 & 71.175 \\
\hline $\begin{array}{l}\text { Oky } \\
\text { Oktaviani }\end{array}$ & 3.5 & 34 & 3.53 & 72.375 \\
\hline $\begin{array}{l}\text { Edwin } \\
\text { Erdiyana }\end{array}$ & 3.3 & 34 & 3.89 & 73.075 \\
\hline Drajat & 2.3 & 29 & 3.2 & 64.575 \\
\hline $\begin{array}{l}\text { Ega } \\
\text { Suhandianto }\end{array}$ & 3 & 32 & 3.5 & 70 \\
\hline Inda Sidik & 3.25 & 31 & 3.5 & 72.5 \\
\hline $\begin{array}{l}\text { Mohamad } \\
\text { Akbar } \\
\text { Nasirudin }\end{array}$ & 3.3 & 36 & 3 & 75 \\
\hline $\begin{array}{l}\text { Santi } \\
\text { Susanti }\end{array}$ & 2.5 & 35 & 3.2 & 64.575 \\
\hline $\begin{array}{l}\text { M. Ridwan } \\
\text { Firdaus }\end{array}$ & 3.55 & 35 & 3.7 & 67.5 \\
\hline $\begin{array}{l}\text { Mohamad } \\
\text { Rizqi } \\
\text { Muladi }\end{array}$ & 3.8 & 30 & 3 & 70.175 \\
\hline
\end{tabular}

p-ISSN : 1858-3911, e-ISSN : 2614-5405

https://journal.uniku.ac.id/index.php/ilkom

\begin{tabular}{|l|c|c|c|c|}
\hline $\begin{array}{l}\text { Novia Dwi } \\
\text { Anggraeni }\end{array}$ & 3.3 & 34 & 3.6 & 72 \\
\hline $\begin{array}{l}\text { Pradika } \\
\text { Gusti } \\
\text { Aryable }\end{array}$ & 3.5 & 38 & 3.7 & 75 \\
\hline
\end{tabular}

\subsection{Perhitungan Metode AHP}

Calon asisten laboratorium harus mengikuti beberapa tes yang nantinya dijadikan sebagai kriteria dalam perhitungan metode AHP. Untuk nilai wawancara sebagai kriteria 1, tes tertulis sebagai kriteria ke 2, nilai akademik sebagai kriteria ke 3, dan microteaching sebagai kriteria ke 4. Sedangkan alternative yang berkaitan dengan kriteria tersebut berupa nama calon asisten laboratotium. Adapun kriteria dan alternative yang digunakan yaitu :

Tabel 3. Kriteria Pada AHP

\begin{tabular}{|c|l|r|r|r|r|}
\hline Ai & \multicolumn{1}{|c|}{ Alternatif } & C1 & \multicolumn{1}{c|}{$\mathbf{2}$} & \multicolumn{1}{c|}{$\mathbf{C 3}$} & \multicolumn{1}{c|}{$\mathbf{C 4}$} \\
\hline A1 & Wulan Noviana N & 3.15 & 30 & 3.5 & 70.1 \\
\hline A2 & Elis & 2 & 36 & 3.63 & 64.15 \\
\hline A3 & Elsa Maitsa & 3.5 & 38 & 3.5 & 74.725 \\
\hline A4 & Mirna Sulistiani & 2.3 & 31 & 3.67 & 74.85 \\
\hline A5 & $\begin{array}{l}\text { Idam Idzin } \\
\text { Dimiati }\end{array}$ & 3.55 & 36 & 3.58 & 73.875 \\
\hline A6 & Yani Suryani & 2.6 & 30 & 3.6 & 67.8 \\
\hline A7 & Intan Nur Fitri & 3.1 & 35 & 3.5 & 71.5 \\
\hline A8 & $\begin{array}{l}\text { Assyfa Savitri } \\
\text { Damayanti }\end{array}$ & 3.2 & 32 & 3.5 & 70.5 \\
\hline A9 & Ero Rohim & 3.6 & 35 & 3.6 & 74.6 \\
\hline A10 & $\begin{array}{l}\text { Amelya Puspita } \\
\text { Anggraeni }\end{array}$ & 2.55 & 31 & 3.55 & 73.775 \\
\hline A11 & Cici Cahyani & 3.55 & 32 & 3.7 & 71.175 \\
\hline A12 & Oky Oktaviani & 3.5 & 34 & 3.53 & 72.375 \\
\hline A13 & Edwin Erdiyana & 3.3 & 34 & 3.89 & 73.075 \\
\hline A14 & Drajat & 2.3 & 29 & 3.2 & 64.575 \\
\hline A15 & Ega Suhandianto & 3 & 32 & 3.5 & 70 \\
\hline A16 & Inda Sidik & 3.25 & 31 & 3.5 & 72.5 \\
\hline A17 & $\begin{array}{l}\text { Mohamad Akbar } \\
\text { Nasirudin }\end{array}$ & 3.3 & 36 & 3 & 75 \\
\hline A18 & Santi Susanti & 2.5 & 35 & 3.2 & 64.575 \\
\hline A19 & $\begin{array}{l}\text { M. Ridwan } \\
\text { Firdaus }\end{array}$ & 3.55 & 35 & 3.7 & 67.5 \\
\hline A20 & $\begin{array}{l}\text { Mohamad Rizqi } \\
\text { Muladi }\end{array}$ & 3.8 & 30 & 3 & 70.175 \\
\hline A21 & $\begin{array}{l}\text { Novia Dwi } \\
\text { Anggraeni }\end{array}$ & 3.3 & 34 & 3.6 & 72 \\
\hline
\end{tabular}


JURNAL NUANSA INFORMATIKA

Volume 14 Nomor 2, Juli 2020

\begin{tabular}{|l|ll|l|l|l|l|}
\hline A22 & $\begin{array}{l}\text { Pradika } \\
\text { Aryable }\end{array}$ & Gusti & 3.5 & 38 & 3.7 & 75 \\
\hline
\end{tabular}

Selanjutnya kriteria tersebut diberikan bobot yang diperoleh berdasarkan hasil wawancara langsung kepada pihak laboratorium FKOM yang bertanggung jawab terhadap proses seleksi penerimaan asisten laboratorium. Tabel 4. merupakan nilai pembobotan terhadap kriteria :

Tabel 4. Pembobotan Kriteria

\begin{tabular}{|c|c|c|}
\hline Kriteria & $\begin{array}{c}\text { Derajat } \\
\text { Kepentingan }\end{array}$ & Kriteria \\
\hline Nilai Wawancara & $1 / 5 \mathrm{x}$ & Tes Tertulis \\
\hline Nilai Wawancara & $1 / 6 \mathrm{x}$ & Nilai Akademik \\
\hline Nilai Wawancara & $1 / 3 \mathrm{x}$ & Microteaching \\
\hline Tes Tertulis & $1 / 2 \mathrm{x}$ & Nilai Akademik \\
\hline Tes Tertulis & $3 \mathrm{x}$ & Microteaching \\
\hline Nilai Akademik & $5 \mathrm{x}$ & Microteaching \\
\hline
\end{tabular}

Untuk bobot kriteria nilai akademik lima kali lebih penting dibandingkan dengan microteaching sehingga bobot kriteria microteaching dibandingkan dengan nilai akademik merupakan kebalikan yaitu $1 / 5$ kali lebih penting, dan seterusnya. Tabel 4. merupakan data untuk dilakukan perhitungan dengan metode AHP.

Tahap pertama dalam perhitungan menggunakan metode AHP yaitu dengan menyusun hirarki yang diawali dengan kriteria dan alternative untuk menetapkan perbandingan berpasangan dalam bentuk matriks. Nilai perbandingan berpasangan berdasarkan pembobotan yang mengacu pada kriteria. Hasil rekapitulasi data dari pembobotan kriteria dalam matriks berpasangan seperti berikut :

Tabel 5. Matriks berpasangan untuk kriteria

\begin{tabular}{|c|c|c|c|c|}
\hline $\begin{array}{c}\text { Perbandingan } \\
\text { Kriteria }\end{array}$ & Wawancara & $\begin{array}{c}\text { Tes } \\
\text { Tertulis }\end{array}$ & $\begin{array}{c}\text { Nilai } \\
\text { Akademik }\end{array}$ & $\begin{array}{c}\text { Micro } \\
\text { teaching }\end{array}$ \\
\hline Wawancara & 1 & 0.2 & 0.17 & 0.3 \\
\hline $\begin{array}{c}\text { Tes } \\
\text { Tertulis }\end{array}$ & 5 & 1 & 0.5 & 3 \\
\hline
\end{tabular}

Nilai indeks konsistensi (CI) bertujuan tuk mengetahui konsistensi jawaban yang akan berpengaruh pada tingkat akurasi dari hasil yang diperoleh.

p-ISSN : 1858-3911, e-ISSN : 2614-5405

https://journal.uniku.ac.id/index.php/ilkom

\begin{tabular}{|c|c|c|c|c|}
\hline Nilai Akademik & 6 & 2 & 1 & 5 \\
\hline Microteaching & 3 & 0.3 & 0.2 & 1 \\
\hline Jumlah & 15 & 3.5 & 1.87 & 9.3 \\
\hline
\end{tabular}

Tahap selanjutnya yaitu menghitung prioritas masing-masing kriteria dengan cara membagi matriks perbandingan berpasangan dengan jumlah kolom yang bersesuaian, dan menjumlahkan perbaris. Kemudian hasil penjumlahan dibagi dengan banyaknya kriteria sehingga ditemukan bobot prioritas. Untuk perhitungan prioritas dapat dilihat pada tabel 6 .

Tabel 6. Hasil rekapitulasi prioritas nilai kriteria

\begin{tabular}{|c|c|c|c|c|c|c|}
\hline & C1 & C2 & C3 & C4 & Jumlah & Prioritas \\
\hline C1 & 0.06 & 0.05 & 0.09 & 0.03 & 0.23 & 0.058 \\
\hline C2 & 0.3 & 0.28 & 0.267 & 0.32 & 1.16 & 0.29 \\
\hline C3 & 0.4 & 0.57 & 0.53 & 0.537 & 2.037 & 0.51 \\
\hline C4 & 0.2 & 0.085 & 0.10 & 0.10 & 0.485 & 0.12 \\
\hline
\end{tabular}

Kemudian hasil rekapitulasi nilai prioritas dari tabel diatas dikalikan dengan matriks perbandingan pada tabel 5. untuk menghasilkan matriks penjumlahan seperti pada tabel 7 .

Tabel 7. Matriks penjumlahan

\begin{tabular}{|c|c|c|c|c|c|}
\hline & $\mathrm{C} 1$ & $\mathrm{C} 2$ & $\mathrm{C} 3$ & $\mathrm{C} 4$ & Jumlah \\
\hline $\mathrm{C} 1$ & 0.08 & 0.058 & 0.08 & 0.03 & 0.248 \\
\hline $\mathrm{C} 2$ & 0.95 & 0.29 & 0.25 & 0.3 & 1.79 \\
\hline $\mathrm{C} 3$ & 0.14 & 0.58 & 0.50 & 0.5 & 1.72 \\
\hline $\mathrm{C} 4$ & 0.57 & 0.087 & 0.1 & 0.1 & 0.857 \\
\hline
\end{tabular}

Tahap berikutnya yaitu menghitung rasio konsistensi untuk memastikan bahwa nilai rasio konsistensi $(\mathrm{CR})<=0.1$, jika nilainya lebih besar dari 0.1 maka matriks perbandingan berpasangan harus diperbaiki. Adapun rumus perhitungan $\mathrm{CR}$ yaitu :

$$
\mathrm{CR}=\mathrm{CI} / \mathrm{RI}
$$

Nilai RI merupakan nilai random indeks yang dikeluarkan oleh Oarkridge Laboratory yang berupa tabel berikut :

Tabel 8. Nilai Random Index

\begin{tabular}{|l|l|l|l|l|l|l|l|l|l|l|}
\hline $\mathrm{N}$ & 1 & 2 & 3 & 4 & 5 & 6 & 7 & 8 & 9 & 10 \\
\hline $\mathrm{RI}$ & 0 & 0 & 0.58 & 0.90 & 1.12 & 1.24 & 1.32 & 1.41 & 1.45 & 1.49 \\
\hline
\end{tabular}$$
\text { hasil yang diperoleh. }
$$ 
JURNAL NUANSA INFORMATIKA

Volume 14 Nomor 2, Juli 2020

Rumus perhitungan CI sebagai berikut :

$\mathrm{CI}=\left(\lambda_{\max }-\mathrm{n}\right) /(\mathrm{n}-1)$

Untuk mengetahui $\lambda_{\text {max }}$ dapat diambil dari tabel di bawah ini :

Tabel 9. Perhitungan $\lambda_{\text {max }}$

\begin{tabular}{|c|c|c|c|}
\hline & $\begin{array}{c}\text { Jumlah Matriks } \\
\text { Penjumlahan }\end{array}$ & Prioritas & Hasil \\
\hline C1 & 0.248 & 0.058 & 0.298 \\
\hline C2 & 1.79 & 0.29 & 2.08 \\
\hline C3 & 1.72 & 0.51 & 2.22 \\
\hline C4 & 0.857 & 0.12 & 0.957 \\
\hline \multicolumn{3}{|c|}{ Jumlah } & 5.6 \\
\hline
\end{tabular}

Berdasarkan tabel diatas maka nilai Consistency Index dapat diperoleh dari perhitungan seperti berikut :

$\mathrm{CI}=(\lambda \max -\mathrm{n}) /(\mathrm{n}-1) ;$ dimana $\mathrm{n}$ :

banyaknya kriteria

$\mathrm{CI}=((5.6 / 4)-4) /(4-1)$

$\mathrm{CI}=(1.4-4) / 3$

$\mathrm{CI}=-0.86$

Untuk $n$ bernilai 4 , maka nilai RI adalah 0,90. Dengan demikian, nilai CR pada kriteria adalah $-0.86 / 0,90=-0.95$. Karena nilai CR $<=0,100$ maka rasio konsistensi perhitungan dapat diterima dan dapat ke tahap selanjutnya, yaitu melakukan perhitungan alternatif masing-masing kriteria untuk mendapatkan prioritas. Berikut ini tabel prioritas untuk setiap alternative.

Tabel 10. Perhitungan prioitas untuk alternative

\begin{tabular}{|c|c|c|c|c|}
\hline $\begin{array}{c}\text { Prioritas } \\
\text { Kriteria }\end{array}$ & 0.058 & 0.29 & 0.51 & 0.12 \\
\hline & $\mathrm{C} 1$ & $\mathrm{C} 2$ & $\mathrm{C} 3$ & $\mathrm{C} 4$ \\
\hline A1 & 0.047 & 0.041 & 0.046 & 0.045 \\
\hline A2 & 0.03 & 0.05 & 0.048 & 0.042 \\
\hline A3 & 0.052 & 0.052 & 0.046 & 0.048 \\
\hline A4 & 0.034 & 0.043 & 0.048 & 0.048 \\
\hline A5 & 0.052 & 0.05 & 0.047 & 0.048 \\
\hline A6 & 0.038 & 0.041 & 0.047 & 0.044 \\
\hline A7 & 0.046 & 0.048 & 0.046 & 0.046 \\
\hline A8 & 0.047 & 0.044 & 0.046 & 0.046 \\
\hline A9 & 0.053 & 0.048 & 0.047 & 0.048 \\
\hline A10 & 0.038 & 0.043 & 0.047 & 0.048 \\
\hline A11 & 0.052 & 0.044 & 0.048 & 0.046 \\
\hline A12 & 0.052 & 0.047 & 0.046 & 0.047 \\
\hline A13 & 0.049 & 0.047 & 0.051 & 0.047 \\
\hline A14 & 0.034 & 0.04 & 0.042 & 0.042 \\
\hline A15 & 0.044 & 0.044 & 0.046 & 0.045 \\
\hline A16 & 0.048 & 0.043 & 0.046 & 0.047 \\
\hline
\end{tabular}

p-ISSN : 1858-3911, e-ISSN : 2614-5405

https://journal.uniku.ac.id/index.php/ilkom

\begin{tabular}{|c|c|c|c|c|}
\hline A17 & 0.049 & 0.05 & 0.039 & 0.048 \\
\hline A18 & 0.037 & 0.048 & 0.042 & 0.042 \\
\hline A19 & 0.052 & 0.048 & 0.048 & 0.044 \\
\hline A20 & 0.056 & 0.041 & 0.039 & 0.045 \\
\hline A21 & 0.049 & 0.047 & 0.047 & 0.047 \\
\hline A22 & 0.052 & 0.052 & 0.048 & 0.048 \\
\hline
\end{tabular}

Tahap selanjutnya yaitu mengalikan prioritas alternative setiap kriteria dengan bobot prioritas kriteria kemudian menjumlahkannya untuk mendapatkan urutan rangking. Hasilnya dapat dilihat pada tabel 11.

Tabel 11. Perhitungan rangking

\begin{tabular}{|c|c|c|c|c|c|}
\hline & $\mathrm{C} 1$ & $\mathrm{C} 2$ & C3 & $\mathrm{C} 4$ & Jumlah \\
\hline $\begin{array}{l}\text { Wulan Noviana } \\
\mathrm{N}\end{array}$ & 0.0028 & 0.012 & 0.024 & 0.0054 & 0.0442 \\
\hline Elis & 0.0018 & 0.015 & 0.025 & 0.0051 & 0.0469 \\
\hline Elsa Maitsa & 0.0031 & 0.016 & 0.024 & 0.0058 & 0.0489 \\
\hline Mirna Sulistiani & 0.002 & 0.013 & 0.025 & 0.0058 & 0.0458 \\
\hline $\begin{array}{ll}\text { Idam } & \text { Idzin } \\
\text { Dimiati } & \\
\end{array}$ & 0.0031 & 0.015 & 0.024 & 0.0058 & 0.0479 \\
\hline Yani Suryani & 0.0023 & 0.012 & 0.024 & 0.0053 & 0.0436 \\
\hline Intan Nur Fitri & 0.0027 & 0.014 & 0.024 & 0.0056 & 0.0463 \\
\hline $\begin{array}{l}\text { Assyfa Savitri } \\
\text { Damayanti }\end{array}$ & 0.0028 & 0.013 & 0.024 & 0.0056 & 0.0454 \\
\hline Ero Rohim & 0.0031 & 0.014 & 0.024 & 0.0058 & 0.0469 \\
\hline $\begin{array}{l}\text { Amelya Puspita } \\
\text { Anggraeni }\end{array}$ & 0.0023 & 0.013 & 0.024 & 0.0058 & 0.0451 \\
\hline Cici Cahyani & 0.0031 & 0.013 & 0.025 & 0.0056 & 0.0467 \\
\hline Oky Oktaviani & 0.0031 & 0.014 & 0.024 & 0.0057 & 0.0468 \\
\hline Edwin Erdiyana & 0.0029 & 0.014 & 0.026 & 0.0057 & 0.0486 \\
\hline Drajat & 0.002 & 0.012 & 0.022 & 0.0051 & 0.0411 \\
\hline Ega Suhandianto & 0.0026 & 0.013 & 0.024 & 0.0054 & 0.045 \\
\hline Inda Sidik & 0.0028 & 0.013 & 0.024 & 0.0057 & 0.0455 \\
\hline $\begin{array}{l}\text { Mohamad Akbar } \\
\text { Nasirudin }\end{array}$ & 0.0029 & 0.015 & 0.02 & 0.0058 & 0.0437 \\
\hline Santi Susanti & 0.0022 & 0.014 & 0.022 & 0.0051 & 0.0433 \\
\hline $\begin{array}{ll}\text { M. Ridwan } \\
\text { Firdaus }\end{array}$ & 0.0031 & 0.014 & 0.025 & 0.0053 & 0.0474 \\
\hline $\begin{array}{l}\text { Mohamad Rizqi } \\
\text { Muladi }\end{array}$ & 0.0033 & 0.012 & 0.02 & 0.0054 & 0.0407 \\
\hline $\begin{array}{ll}\text { Novia } & \text { Dwi } \\
\text { Anggraeni } & \end{array}$ & 0.0029 & 0.014 & 0.024 & 0.0057 & 0.0466 \\
\hline $\begin{array}{ll}\text { Pradika } & \text { Gusti } \\
\text { Aryable } & \end{array}$ & 0.0031 & 0.016 & 0.025 & 0.0058 & 0.0499 \\
\hline
\end{tabular}

Berdasarkan tabel 11. maka dapat diperoleh urutan rangking dari hasil perhitungan dengan metode AHP seperti berikut ini :

Tabel 12. Hasil urutan rangking dengan metode AHP

\begin{tabular}{|l|c|c|}
\hline & Hasil & Rangking \\
\hline Pradika Gusti Aryable & 0.0499 & 1 \\
\hline Elsa Maitsa & 0.0489 & 2 \\
\hline Edwin Erdiyana & 0.0486 & 3 \\
\hline
\end{tabular}


JURNAL NUANSA INFORMATIKA

Volume 14 Nomor 2, Juli 2020
p-ISSN : 1858-3911, e-ISSN : 2614-5405

https://journal.uniku.ac.id/index.php/ilkom

\begin{tabular}{|l|l|l|}
\hline Yani Suryani & 0.0436 & Ditolak \\
\hline Santi Susanti & 0.0433 & Ditolak \\
\hline Drajat & 0.0411 & Ditolak \\
\hline Mohamad Rizqi Muladi & 0.0407 & Ditolak \\
\hline
\end{tabular}

\subsection{Perhitungan Metode TOPSIS}

Tahap pertama dalam perhitungan menggunakan metode TOPSIS yaitu menentukan rentang nilai dari masing-masing kriteria berdasarkan bobot $(0=$ sangat tidak memuaskan, $0.5=$ cukup, $0.75=$ memuaskan, 1 = sangat memuaskan).

Berdasarkan data hasil tes calon asisten laboratorium pada table 2. maka dapat diperoleh bobot masing-masing kriteria pada tabel 15.

Table 15. Bobot kriteria

\begin{tabular}{|c|c|c|c|c|}
\hline Kriteria & $\begin{array}{l}\text { Nilai } \\
\text { Wawancara }\end{array}$ & $\begin{array}{l}\text { Nilai } \\
\text { Tertulis }\end{array}$ & $\begin{array}{l}\text { Nilai } \\
\text { Akademik }\end{array}$ & $\begin{array}{l}\text { Nilai } \\
\text { Microteaching }\end{array}$ \\
\hline 1 & 3.1 & 41 & 3.1 & 82 \\
\hline 0.75 & 2.4 & 30 & 2.4 & 70 \\
\hline 0.5 & 1.5 & 24 & 1.5 & 59 \\
\hline 0 & 1.4 & 23 & 1.4 & 58 \\
\hline
\end{tabular}

Kemudian konversi bobot kriteria ke dalam bentuk fuzzy sehingga diperoleh seperti tabel 16.

Tabel 16. Konversi bobot kriteria

Tabel 14. Asisten laboratorium terpilih
\begin{tabular}{|l|c|c|}
\hline \multicolumn{1}{|c|}{ Alternatif } & Nilai $C I$ & Status \\
\hline Pradika Gusti Aryable & 0.0499 & Dipertimbangkan \\
\hline Elsa Maitsa & 0.0489 & Ditolak \\
\hline Edwin Erdiyana & 0.0486 & Ditolak \\
\hline Idam Idzin Dimiati & 0.0479 & Ditolak \\
\hline M. Ridwan Firdaus & 0.0474 & Ditolak \\
\hline Elis & 0.0469 & Ditolak \\
\hline Ero Rohim & 0.0469 & Ditolak \\
\hline Oky Oktaviani & 0.0468 & Ditolak \\
\hline Cici Cahyani & 0.0467 & Ditolak \\
\hline Novia Dwi Anggraeni & 0.0466 & Ditolak \\
\hline Intan Nur Fitri & 0.0463 & Ditolak \\
\hline Mirna Sulistiani & 0.0458 & Ditolak \\
\hline Inda Sidik Savitri & 0.0455 & Ditolak \\
\hline $\begin{array}{l}\text { Assyfa Pamayanti } \\
\text { Damayata }\end{array}$ & 0.0454 & Ditolak \\
\hline $\begin{array}{l}\text { Amelya } \\
\text { Anggraeni }\end{array}$ & 0.0451 & Ditolak \\
\hline Ega Suhandianto & 0.045 & Ditolak \\
\hline Wulan Noviana N & 0.0442 & Ditolak \\
\hline $\begin{array}{l}\text { Mohamad Akbar } \\
\text { Nasirudin }\end{array}$ & 0.0437 & Ditolak \\
\hline
\end{tabular}

\begin{tabular}{|c|l|r|r|r|r|}
\hline Ai & \multicolumn{1}{|c|}{ Alternatif } & \multicolumn{1}{c|}{ C1 } & \multicolumn{1}{c|}{ C2 } & \multicolumn{1}{c|}{ C3 } & \multicolumn{1}{c|}{ C4 } \\
\hline A1 & Wulan Noviana N & 1 & 0.5 & 1 & 0.75 \\
\hline A3 & Elis & 0.75 & 0.75 & 1 & 0.5 \\
\hline A4 & Mirna Sulistiani & 0.5 & 0.75 & 1 & 0.75 \\
\hline A5 & Idam Idzin Dimiati & 1 & 0.75 & 1 & 0.75 \\
\hline A6 & Yani Suryani & 1 & 0.75 & 1 & 0.5 \\
\hline A7 & Intan Nur Fitri & 0.75 & 0.75 & 1 & 0.75 \\
\hline A8 & $\begin{array}{l}\text { Assyfa Savitri } \\
\text { Damayanti }\end{array}$ & 0.5 & 0.75 & 1 & 0.75 \\
\hline A9 & Ero Rohim & 1 & 0.75 & 1 & 0.75 \\
\hline A10 & $\begin{array}{l}\text { Amelya Puspita } \\
\text { Anggraeni }\end{array}$ & 0.5 & 0.75 & 1 & 0.75 \\
\hline A11 & Cici Cahyani & 1 & 0.75 & 1 & 0.75 \\
\hline A12 & Oky Oktaviani & 1 & 0.75 & 1 & 0.75 \\
\hline A13 & Edwin Erdiyana & 1 & 0.75 & 1 & 0.75 \\
\hline A14 & Drajat & 0.5 & 0.5 & 1 & 0.5 \\
\hline
\end{tabular}


JURNAL NUANSA INFORMATIKA

Volume 14 Nomor 2, Juli 2020

\begin{tabular}{|c|c|c|c|c|c|}
\hline A15 & Ega Suhandianto & 0.75 & 0.75 & 1 & 0.75 \\
\hline A16 & Inda Sidik & 1 & 0.75 & 1 & 0.75 \\
\hline A17 & $\begin{array}{l}\text { Mohamad Akbar } \\
\text { Nasirudin }\end{array}$ & 1 & 1 & 0.75 & 0.75 \\
\hline A18 & Santi Susanti & 0.75 & 0.75 & 1 & 0.5 \\
\hline A19 & M. Ridwan Firdaus & 1 & 0.75 & 1 & 0.5 \\
\hline A20 & $\begin{array}{l}\text { Mohamad Rizqi } \\
\text { Muladi }\end{array}$ & 1 & 0.75 & 0.75 & 0.75 \\
\hline A21 & $\begin{array}{ll}\text { Novia } & \text { Dwi } \\
\text { Anggraeni } & \\
\end{array}$ & 1 & 0.75 & 1 & 0.75 \\
\hline A22 & $\begin{array}{ll}\text { Pradika } & \text { Gusti } \\
\text { Aryable } & \end{array}$ & 1 & 0.75 & 1 & 0.75 \\
\hline
\end{tabular}

Tahap selanjutnya menghitung matriks ternormalisasi dengan menggunakan rumus:

$$
R_{i j}=\frac{x_{i j}}{\sqrt{\sum_{i=1}^{m} x_{i j}^{2}}}
$$

Dimana $: i=1,2 \ldots \ldots, m ;$ dan $j=1,2, \ldots \ldots, n$

Sehingga nilai untuk X1, X2, X3, dan X4 dapat dilihat pada table 17.

Tabel 17. Tabel X

\begin{tabular}{|c|c|c|c|c|}
\hline $\mathrm{X}$ & 1 & 2 & 3 & 4 \\
\hline Hasil & 4.15 & 3.49 & 4.59 & 3.3 \\
\hline
\end{tabular}

Sedangkan untuk matriks ternormalisasi dapat dilihat pada tabel 18 .

Tabel 18. Matriks ternormalisasi

\begin{tabular}{|l|c|c|c|c|}
\hline \multicolumn{1}{|c|}{ Alternatif } & $\mathrm{C} 1$ & $\mathrm{C} 2$ & $\mathrm{C} 3$ & $\mathrm{C} 4$ \\
\hline Wulan Noviana N & 0.241 & 0.143 & 0.218 & 0.228 \\
\hline Elis & 0.181 & 0.215 & 0.218 & 0.152 \\
\hline Elsa Maitsa & 0.241 & 0.215 & 0.218 & 0.228 \\
\hline Mirna Sulistiani & 0.120 & 0.215 & 0.218 & 0.228 \\
\hline $\begin{array}{l}\text { Idam Idzin } \\
\text { Dimiati }\end{array}$ & 0.241 & 0.215 & 0.218 & 0.228 \\
\hline Yani Suryani & 0.241 & 0.215 & 0.218 & 0.152 \\
\hline Intan Nur Fitri & 0.181 & 0.215 & 0.218 & 0.228 \\
\hline $\begin{array}{l}\text { Assyfa Savitri } \\
\text { Damayanti }\end{array}$ & 0.120 & 0.215 & 0.218 & 0.228 \\
\hline Ero Rohim & 0.241 & 0.215 & 0.218 & 0.228 \\
\hline $\begin{array}{l}\text { Amelya Puspita } \\
\text { Anggraeni }\end{array}$ & 0.120 & 0.215 & 0.218 & 0.228 \\
\hline Cici Cahyani & 0.241 & 0.215 & 0.218 & 0.228 \\
\hline Oky Oktaviani & 0.241 & 0.215 & 0.218 & 0.228 \\
\hline Edwin Erdiyana & 0.241 & 0.215 & 0.218 & 0.228 \\
\hline Drajat & 0.120 & 0.143 & 0.218 & 0.152 \\
\hline Ega Suhandianto & 0.181 & 0.215 & 0.218 & 0.228 \\
\hline
\end{tabular}

p-ISSN : 1858-3911, e-ISSN : 2614-5405

https://journal.uniku.ac.id/index.php/ilkom

\begin{tabular}{|c|c|c|c|c|}
\hline Inda Sidik & 0.241 & 0.215 & 0.218 & 0.228 \\
\hline $\begin{array}{ll}\text { Mohamad } & \text { Akbar } \\
\text { Nasirudin } & \\
\end{array}$ & 0.241 & 0.286 & 0.163 & 0.228 \\
\hline Santi Susanti & 0.181 & 0.215 & 0.218 & 0.152 \\
\hline $\begin{array}{ll}\text { M. } & \text { Ridwan } \\
\text { Firdaus } & \\
\end{array}$ & 0.241 & 0.215 & 0.218 & 0.152 \\
\hline $\begin{array}{l}\text { Mohamad Rizqi } \\
\text { Muladi }\end{array}$ & 0.241 & 0.215 & 0.163 & 0.228 \\
\hline $\begin{array}{ll}\text { Novia } & \text { Dwi } \\
\text { Anggraeni } & \\
\end{array}$ & 0.241 & 0.215 & 0.218 & 0.228 \\
\hline $\begin{array}{l}\text { Pradika } \\
\text { Aryable }\end{array}$ & 0.241 & 0.215 & 0.218 & 0.228 \\
\hline
\end{tabular}

Tahap selanjutnya yaitu menghitung matriks ternormalisasi dengan terbobot $(\mathrm{Y})$. Dimana, untuk nilai bobot $(\mathrm{Y})$ dapat dilihat pada tabel 19.

Tabel 19. Bobot(Y) yang ditentukan

\begin{tabular}{|l|l|c|}
\hline \multicolumn{2}{|c|}{ KRITERIA } & W \\
\hline C1 & nilai wawancara & 1 \\
\hline C2 & tes tertulis & 0.75 \\
\hline C3 & nilai akademik & 1 \\
\hline C4 & microteaching & 1 \\
\hline
\end{tabular}

Untuk perhitungan matriks ternormalisasi dengan bobot $(\mathrm{Y})$ dapat menggunakan rumus berikut :

yij $=$ wi*rij ; dengan $i=1,2, \ldots, m$; dan $j=1,2$, $\ldots, n$

Hal ini dilakukan sampai calon asisten laboratorium ke-22. Adapun hasilnya dapat dilihat pada tabel 20.

Tabel 20. Tabel ternormalisasi Y

\begin{tabular}{|l|c|c|c|c|}
\hline \multicolumn{1}{|c|}{ Alternatif } & C1 & C2 & C3 & C4 \\
\hline Wulan Noviana N & 0.241 & 0.10725 & 0.218 & 0.228 \\
\hline Elis & 0.181 & 0.16125 & 0.218 & 0.152 \\
\hline Elsa Maitsa & 0.241 & 0.16125 & 0.218 & 0.228 \\
\hline Mirna Sulistiani & 0.12 & 0.16125 & 0.218 & 0.228 \\
\hline $\begin{array}{l}\text { Idam Idzin } \\
\text { Dimiati }\end{array}$ & 0.241 & 0.16125 & 0.218 & 0.228 \\
\hline Yani Suryani & 0.241 & 0.16125 & 0.218 & 0.152 \\
\hline Intan Nur Fitri & 0.181 & 0.16125 & 0.218 & 0.228 \\
\hline $\begin{array}{l}\text { Assyfa Savitri } \\
\text { Damayanti }\end{array}$ & 0.12 & 0.16125 & 0.218 & 0.228 \\
\hline Ero Rohim & 0.241 & 0.16125 & 0.218 & 0.228 \\
\hline $\begin{array}{l}\text { Amelya Puspita } \\
\text { Anggraeni }\end{array}$ & 0.12 & 0.16125 & 0.218 & 0.228 \\
\hline Cici Cahyani & 0.241 & 0.16125 & 0.218 & 0.228 \\
\hline
\end{tabular}


JURNAL NUANSA INFORMATIKA

Volume 14 Nomor 2, Juli 2020

\begin{tabular}{|l|c|c|c|c|} 
Oky Oktaviani & 0.241 & 0.16125 & 0.218 & 0.228 \\
\hline Edwin Erdiyana & 0.241 & 0.16125 & 0.218 & 0.228 \\
\hline Drajat & 0.12 & 0.10725 & 0.218 & 0.152 \\
\hline Ega Suhandianto & 0.181 & 0.16125 & 0.218 & 0.228 \\
\hline Inda Sidik & 0.241 & 0.16125 & 0.218 & 0.228 \\
\hline $\begin{array}{l}\text { Mohamad Akbar } \\
\text { Nasirudin }\end{array}$ & 0.241 & 0.2145 & 0.163 & 0.228 \\
\hline Santi Susanti & 0.181 & 0.16125 & 0.218 & 0.152 \\
\hline $\begin{array}{l}\text { M. Ridwan } \\
\text { Firdaus }\end{array}$ & 0.241 & 0.16125 & 0.218 & 0.152 \\
\hline $\begin{array}{l}\text { Mohamad Rizqi } \\
\text { Muladi }\end{array}$ & 0.241 & 0.16125 & 0.163 & 0.228 \\
\hline $\begin{array}{l}\text { Novia Dwi } \\
\text { Anggraeni }\end{array}$ & 0.241 & 0.16125 & 0.218 & 0.228 \\
\hline $\begin{array}{l}\text { Pradika Gusti } \\
\text { Aryable }\end{array}$ & 0.241 & 0.16125 & 0.218 & 0.228 \\
\hline
\end{tabular}

Kemudian menentukan solusi ideal positif (A+) dan solusi ideal negative (A-) berdasarkan rumus berikut :

$\mathbf{A}+=\max (\mathbf{y} 1+, \mathbf{y} 2+, \ldots, \mathbf{y n}+)$ dan

A- = $\max (\mathbf{y 1}-, \mathbf{y} 2-, \ldots$, ,yn- $)$

Hasil perhitungannya terdapat pada tabel 21.

Tabel 21. Perhitungan solusi ideal posistif dan negative

\begin{tabular}{|c|c|c|}
\hline Kriteria & $\mathrm{A}+$ & $\mathrm{A}-$ \\
\hline $\mathrm{C} 1$ & 0.241 & 0.12 \\
\hline $\mathrm{C} 2$ & 0.214 & 0.107 \\
\hline $\mathrm{C} 3$ & 0.218 & 0.163 \\
\hline $\mathrm{C} 4$ & 0.228 & 0.152 \\
\hline
\end{tabular}

Langkah selanjutnya menghitung jarak solusi ideal (D+) dan jarak solusi ideal negative (D-) dengan menggunakan rumus berikut :

$\boldsymbol{D}_{i}^{+}=\sqrt{\sum_{j=1}^{n}\left(\boldsymbol{y}_{i}^{+}-\boldsymbol{y}_{i j}\right)^{2}} ; \quad i=1,2, \ldots, m$.

Hal ini dilakukan pada masing-masing alternative. Hasil perhitungannya dapat dilihat pada tabel 22.

Tabel 22. Perhitungan jarak solusi ideal

\begin{tabular}{|l|r|r|}
\hline \multicolumn{1}{|c|}{ Alternatif } & \multicolumn{1}{c|}{ D+ } & \multicolumn{1}{c|}{ D- } \\
\hline Wulan Noviana N & 0.10675 & 0.153108 \\
\hline Elis & 0.110266 & 0.098433 \\
\hline Elsa Maitsa & 0.05275 & 0.162435 \\
\hline Mirna Sulistiani & 0.131998 & 0.10837 \\
\hline Idam Idzin Dimiati & 0.05275 & 0.162435 \\
\hline
\end{tabular}

p-ISSN : 1858-3911, e-ISSN : 2614-5405

https://journal.uniku.ac.id/index.php/ilkom

\begin{tabular}{|l|r|r|} 
Yani Suryani & 0.092512 & 0.143559 \\
\hline Intan Nur Fitri & 0.079891 & 0.124359 \\
\hline Assyfa Savitri Damayanti & 0.131998 & 0.10837 \\
\hline Ero Rohim & 0.05275 & 0.162435 \\
\hline Amelya Puspita Anggraeni & 0.131998 & 0.10837 \\
\hline Cici Cahyani & 0.05275 & 0.162435 \\
\hline Oky Oktaviani & 0.05275 & 0.162435 \\
\hline Edwin Erdiyana & 0.05275 & 0.162435 \\
\hline Drajat & 0.178361 & 0.055001 \\
\hline Ega Suhandianto & 0.079891 & 0.124359 \\
\hline Inda Sidik & 0.05275 & 0.162435 \\
\hline Mohamad Akbar Nasirudin & 0.055002 & 0.178811 \\
\hline Santi Susanti & 0.110266 & 0.098433 \\
\hline M. Ridwan Firdaus & 0.092512 & 0.143559 \\
\hline Mohamad Rizqi Muladi & 0.076207 & 0.15284 \\
\hline Novia Dwi Anggraeni & 0.05275 & 0.162435 \\
\hline Pradika Gusti Aryable & 0.05275 & 0.162435 \\
\hline
\end{tabular}

Selanjutnya menghitung nilai preferensi untuk setiap alternative dengan menggunakan rumus berikut :

$V_{i}=\frac{D_{i}^{-}}{D_{i}^{-}+D_{i}^{+}}$, dimana $i=1,2,3, \ldots m$.

Hasil perhitungan nilai preferensi terdapat pada tabel 23.

Tabel 23. Nilai Preferensi

\begin{tabular}{|l|c|}
\hline \multicolumn{1}{|c|}{ Alternatif } & $\begin{array}{c}\text { Nilai Preferensi } \\
(\mathrm{V})\end{array}$ \\
\hline Wulan Noviana N & 0.589199 \\
\hline Elis & 0.471651 \\
\hline Elsa Maitsa & 0.754862 \\
\hline Mirna Sulistiani & 0.45085 \\
\hline Idam Idzin Dimiati & 0.754862 \\
\hline Yani Suryani & 0.608116 \\
\hline Intan Nur Fitri & 0.608856 \\
\hline Assyfa Savitri Damayanti & 0.45085 \\
\hline Ero Rohim & 0.754862 \\
\hline Amelya Puspita Anggraeni & 0.45085 \\
\hline Cici Cahyani & 0.754862 \\
\hline Oky Oktaviani & 0.754862 \\
\hline Edwin Erdiyana & 0.754862 \\
\hline Drajat & 0.235688 \\
\hline
\end{tabular}


JURNAL NUANSA INFORMATIKA

Volume 14 Nomor 2, Juli 2020

\begin{tabular}{|l|l|}
\hline Ega Suhandianto & 0.608856 \\
\hline Inda Sidik & 0.754862 \\
\hline Mohamad Akbar Nasirudin & 0.764759 \\
\hline Santi Susanti & 0.471651 \\
\hline M. Ridwan Firdaus & 0.608116 \\
\hline Mohamad Rizqi Muladi & 0.667286 \\
\hline Novia Dwi Anggraeni & 0.754862 \\
\hline Pradika Gusti Aryable & 0.754862 \\
\hline
\end{tabular}

Dari perhitungan diatas maka dapat diperoleh pengurutan rangking seperti pada tabel 24 :

Tabel 24. Hasil perhitungan metode TOPSIS

\begin{tabular}{|l|c|c|}
\hline \multicolumn{1}{|c|}{ Alternatif } & $\begin{array}{c}\text { Nilai } \\
\text { Preferensi } \\
\text { (V) }\end{array}$ & Rangking \\
\hline $\begin{array}{l}\text { Mohamad Akbar } \\
\text { Nasirudin }\end{array}$ & 0.76476 & 1 \\
\hline Elsa Maitsa & 0.75486 & 2 \\
\hline Idam Idzin Dimiati & 0.75486 & 3 \\
\hline Ero Rohim & 0.75486 & 4 \\
\hline Cici Cahyani & 0.75486 & 5 \\
\hline Oky Oktaviani & 0.75486 & 6 \\
\hline Edwin Erdiyana & 0.75486 & 7 \\
\hline Inda Sidik Puspita & 0.75486 & 8 \\
\hline Novia Dwi Anggraeni & 0.75486 & 9 \\
\hline Pradika Gusti Aryable & 0.75486 & 10 \\
\hline $\begin{array}{l}\text { Mohamad Rizqi } \\
\text { Muladi }\end{array}$ & 0.66729 & 11 \\
\hline Intan Nur Fitri & 0.60886 & 12 \\
\hline Ega Suhandianto & 0.60886 & 13 \\
\hline Yani Suryani & 0.60812 & 14 \\
\hline M. Ridwan Firdaus & 0.60812 & 15 \\
\hline Wulan Noviana N & 0.5892 & 16 \\
\hline Elis Savitri & 0.47165 & 17 \\
\hline Santi Susanti & 0.47165 & 18 \\
\hline Mirna Sulistiani & 0.45085 & 19 \\
\hline $\begin{array}{l}\text { Assyfa } \\
\text { Damayanti }\end{array}$ & 0.45085 & 20 \\
\hline Amelya Anggraeni & 0.45085 & 21 \\
\hline Drajat & & 22 \\
\hline
\end{tabular}


JURNAL NUANSA INFORMATIKA

Volume 14 Nomor 2, Juli 2020

Komputer Universitas Kuningan maka dapat diketahui perbedaan dari kedua metode tersebut. Kesesuaian antara hasil kedua metode tersebut dengan hasil perangkingan di Laboratorium Fakultas Ilmu Komputer dapat dilihat pada tabel 27.

Tabel 27. Kesesuaian dengan hasil perangkingan Laboratorium FKOM

\begin{tabular}{|l|l|l|}
\hline & \multicolumn{1}{|c|}{ AHP } & \multicolumn{1}{c|}{ TOPSIS } \\
\hline \multirow{3}{*}{ Sesuai } & 1 asisten & 16 asisten \\
& laboratorium & laboratorium \\
& $5 \%$ & $73 \%$ \\
\hline \multirow{2}{*}{ Tidak } & 21 asisten & 6 asisten \\
Sesuai & laboratorium & laboratorium \\
& $95 \%$ & $27 \%$ \\
\hline
\end{tabular}

Dari hasil presentase kesesuaian antara perangkingan Laboratorium FKOM dengan kedua metode seperti pada tabel 3.26 maka metode TOPSIS memperoleh hasil yang paling baik karena memiliki persentase terkecil sehingga mempunyai ketidaksesuaian yang paling kecil dengan hasil ketetapan dari laboratorium Fakultas Ilmu Komputer.

3.3 Merancang dan Membangun Prototyping

Dalam melakukan perancangan sistem penulis menggunakan diagram UML untuk memberikan gambaran terintegrasi terhadap sistem yang akan dibangun. Berikut ini rincian dari perancangannya :

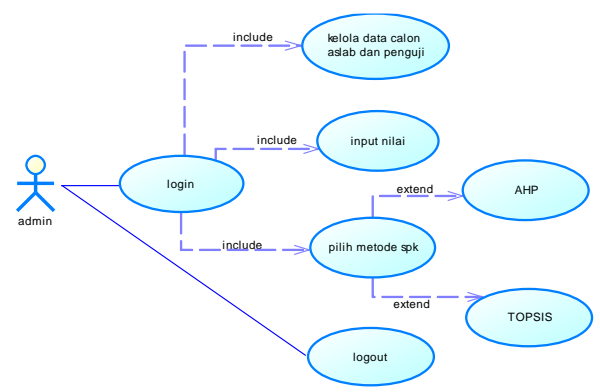

Gambar 4. Diagram Use Case

Aplikasi ini diterapkan dalam bahasa pemrograman PHP dan MySQL. Berikut ini tampilan input dan output pada aplikasi :
p-ISSN : 1858-3911, e-ISSN : 2614-5405

https://journal.uniku.ac.id/index.php/ilkom

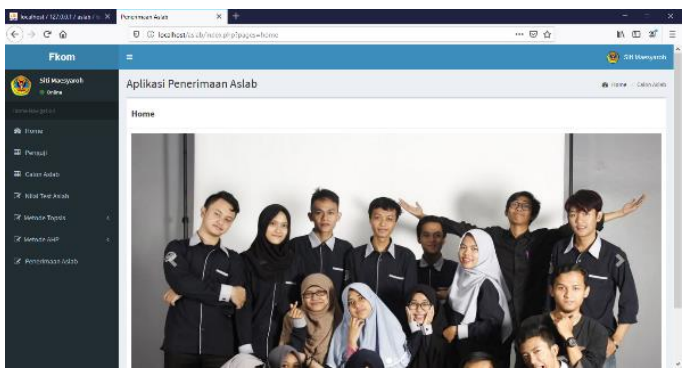

Gambar 5. Halaman Utama

Admin dapat memasukkan nilai tes calon aslab dari penguji dengan menggunakan menu Nilai Tes Aslab.

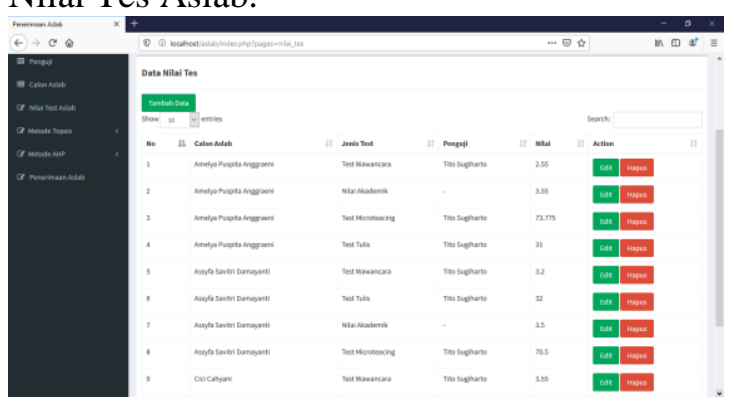

Gambar 6. Halaman Nilai Tes Aslab

Pada menu Metode Topsis terdapat sub menu Bobot Tes dan Nilai Kriteria, dimana admin dapat menginputkan bobot dan nilai dari masing-masing kriteria.

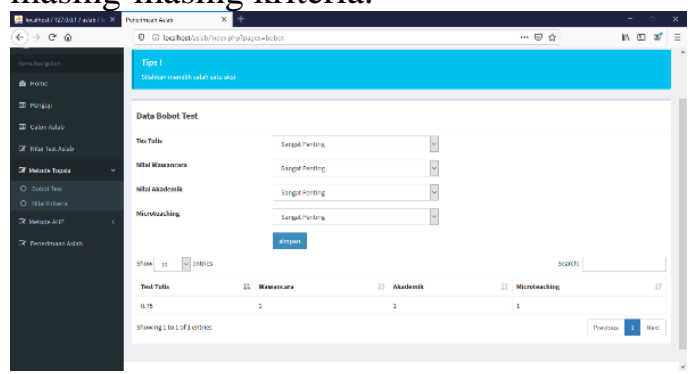

Gambar 7. Halaman Metode Topsis Untuk Bobot Tes

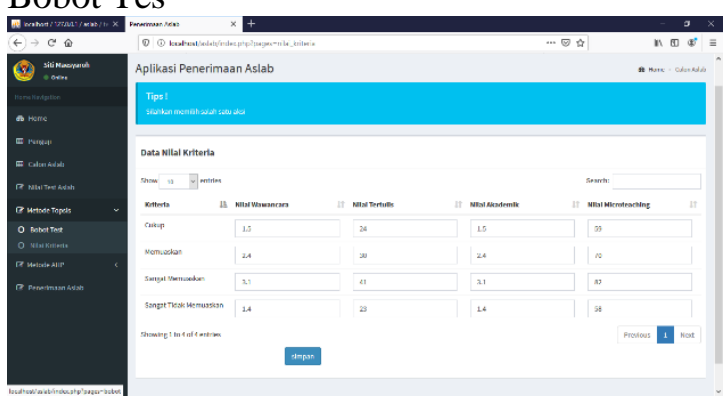

Gambar 8. Halaman Metode Topsis Untuk Nilai Kriteria

Sedangkan menu Metode AHP terdapat satu submenu Perbandingan Kriteria, dimana 
JURNAL NUANSA INFORMATIKA

Volume 14 Nomor 2, Juli 2020

admin dapat menginputkan nilai perbandingan kriteria dalam bentuk matriks.

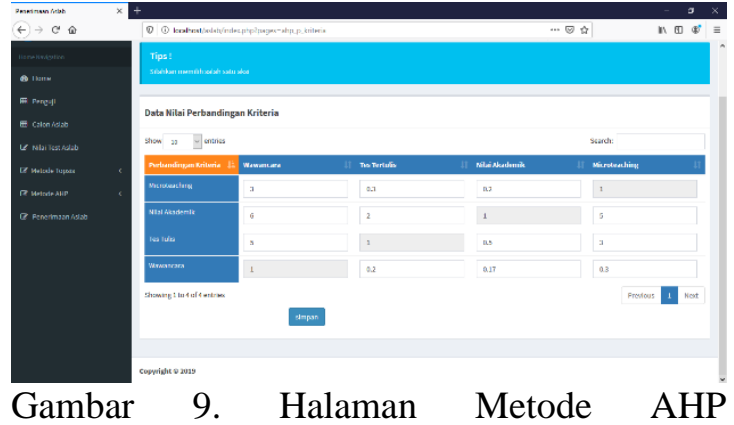

Perbandingan Kriteria

Untuk hasil dari perhitungan kedua metode tersebut dapat dilihat pada menu Penerimaan Aslab.

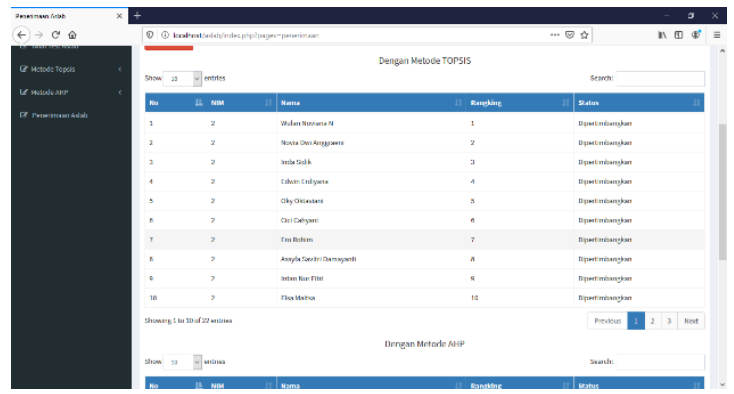

Gambar 10. Halaman Penerimaan Aslab

\section{KESIMPULAN}

Berdasarkan hasil penelitian dan pembahasan maka penulis dapat memberikan kesimpulan sebagai berikut :

a. Hasil pengukuran nilai akurasi metode AHP sebesar $45 \%$ sedangkan metode TOPSIS sebesar 73\%. Hal ini menunjukkan bahwa nilai akurasi TOPSIS lebih besar dibandingkan dengan AHP pada data penerimaan asisten laboratorium sehingga untuk rekomendasi penerimaan asisten laboratorium lebih tepat menggunakan metode TOPSIS.

b. Berdasarkan penelitian sebelumnya yang menggunakan metode AHP dan TOPSIS sebagai penunjang keputusan seperti tercantum pada pendahuluan bahwa metode TOPSIS mempunyai tingkat akurasi yang lebih besar dibandingkan dengan metode AHP walaupun setiap kasus terdapat perbedaan jumlah kriteria dan alternative.

c. Jumlah data kriteria dan alternative tidak mempengaruhi tingkat akurasi data.
p-ISSN : 1858-3911, e-ISSN : 2614-5405

https://journal.uniku.ac.id/index.php/ilkom

d. Hasil dari ini dapat memberikan rekomendasi bagi pihak laboratorium Fakultas Ilmu Komputer untuk memillih dan menerapkan metode sistem pendukung keputusan yang dapat memberikan hasil yang optimal.

\section{DAFTAR PUSTAKA}

Adriyendi \& Melia, Yeni. (2013, March). DSS using AHP in Selection of Lecturer. International Journal of Advanced Science and Technology.

Saaty, T. L., 1993. Pengambilan Keputusan Bagi Para Pemimpin, Proses Hirarki Analitik untuk Pengambilan Keputusan dalam Situasi yang Kompleks. Jakarta : PT. Pustaka Binaman Presindo.

Saaty, T.L. 2000. The Fundamentals of Decision Making and Priority Theory with the Analytic Hierarchy Process. Pittsburgh: RWS Publication University of Pittsburgh.

Sinaga, Johannes. 2009, Penerapan Analytical Hierarchy Process (AHP) Dalam Pemilihan Perusahaan Badan Usaha Milik Negara (BUMN) Sebagai Tempat Kerja Mahasiswa Universitas Sumatera Utara.

Sugiyono. 2015. Metode Penelitian Kombinasi (Mix Methods). Bandung: Alfabeta.

Suwarno, Adi. 2016. Perbadindingan metode AHP dengan metode TOPSIS Untul Menentukan Matakuliah PEminatan Bagi Mahasiswa. Jurnal Teknologi Pelita Bangas-SIGMA. Volume 4 No 1 Maret 2016. ISSN:2407-3903.

Turban, Efraim., Aronson, Jay., Liang Peng Ting. 2005. Decision Support System and Intelligent Systems. New Jersey : Pearson Eduction, Inc.

http://wayanfm.lecture.ub.ac.id/files/2014/04/ FP_SPK_F_D-2013-2014-Ganjil-.pdf diakses 20 Februari 2019

Yoon, K.P. and Hwang, C.L. 1995. Multiple Attribute Decision Making: An Introduction, Sage Publications, Thousand Oaks, CA. 